Journal of Health Science
(Jurnal Ilmu Kesehatan)
$\frac{h t t p s: / / \text { www.ejournalwiraraja.com/index.php/JIK }}{2356-5284 \text { (Print) } \mid 2356-5543 \text { (online) }}$

\title{
Analisis Uji Kesesuaian Pesawat Sinar X Radiografi Mobile Merk Drgem Topaz- 40d Menggunakan X-Ray Multimeter PIRANHA
}

\author{
Agoes Santika Hyperastuty ${ }^{1}$, Yanuar Mukhammad ${ }^{2}$, Sugeng ${ }^{3}$ \\ ${ }^{1,2}$ D-III Teknik Elektro Medik, Universitas Kadiri \\ ${ }^{3}$ PT. Mulya Husada Jaya, Surabaya, \\ ag,santikabks@gmail.com* \\ *Coresponding Author
}

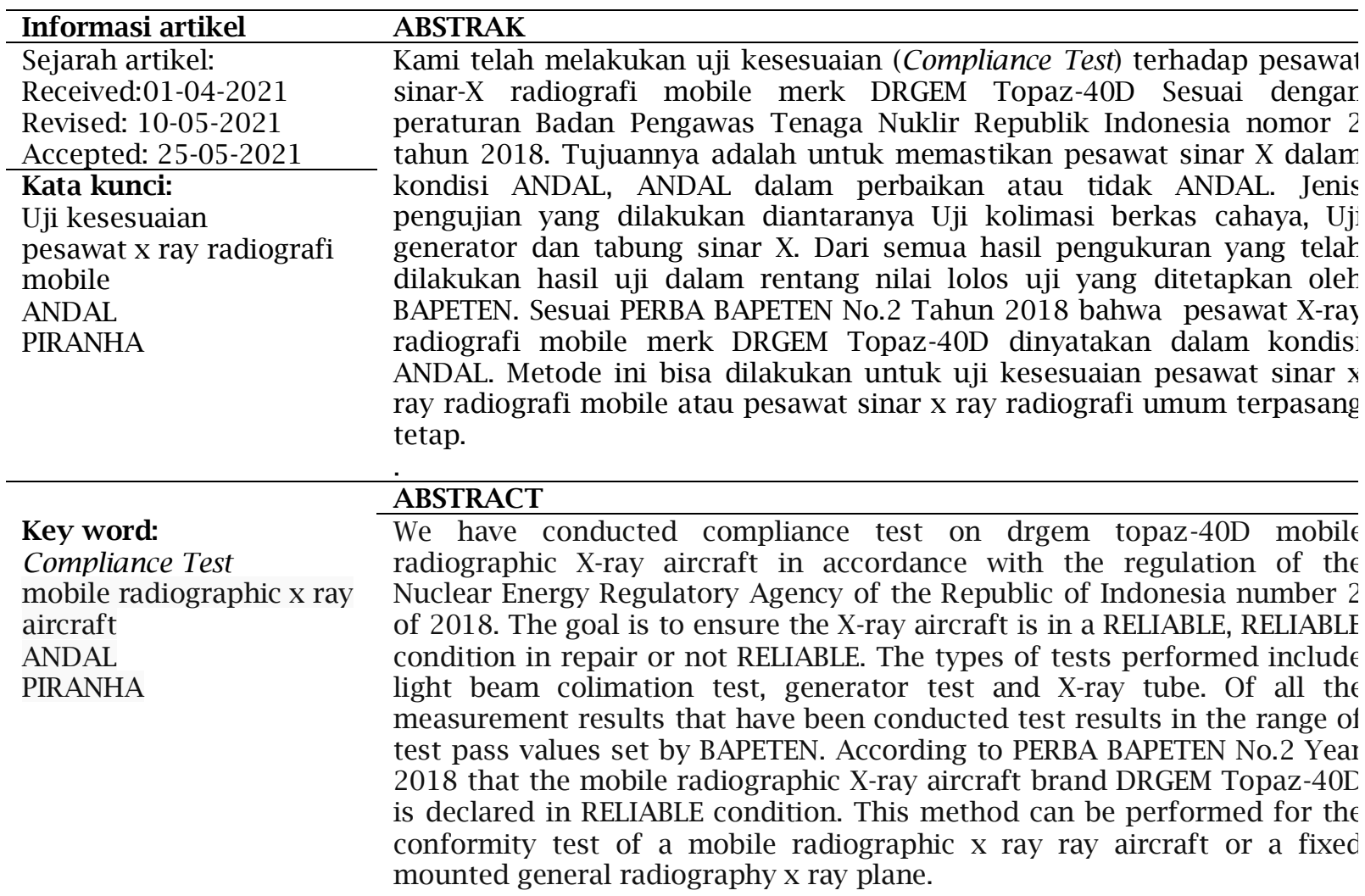

\section{PENDAHULUAN}

Pandemi

berkepanjangan telah menjadi masalah kesehatan di dunia (Suprayitno et al.,2020). Kondisi ini membuat rumah sakit selain membutuhkan tenaga kesehatan seperti dokter dan perawat juga membutuhkan peralatan penunjang untuk memonitoring dan memeriksa kondisi klinis pasien Salah satu peralatan yang diperlukan adalah pesawat sinar $\mathrm{X}$ ray mobile unit. Rumah sakit membutuhkan adanya pesawat sinar
$\mathrm{X}$ ray mobile unit untuk memeriksa kondisi paru-paru pasien penderita covid. Pesawat sinar $X$ ray mobile unit tidak memerlukan instalasi kelistrikan khusus dalam pemasangannya. Karena penggunaan pesawat sinar $\mathrm{X}$ ray mobile unit yang sering dan pemakaian yang berpindah-pindah mengharuskan untuk menguji performa dan kinerja pesawat $X$ ray mobile tersebut terhadap 
pengaruh perubahan kondisi ruangan dan kelistrikannya. Uji kesesuaian pesawat sinar $X$ ray ini juga harus dilakukan sebagai salah satu syarat perizinan pemanfaatan radiasi pengion ke BAPETEN.

Uji kesesuaian dimaksudkan untuk memastikan bahwa peralatan yang digunakan dalam prosedur radiologi diagnostic berfungsi dengan benar sehingga pasien tidak mendapat paparan yang tidak diperlukan, dan menerapkan program jaminan mutu untuk radiologi diagnostik. Pesawat sinar $\mathrm{X}$ radiografi mobile unit adalah pesawat yang mudah dipindahkan dari satu ruangan ke ruangan yang lain. Pesawat sinar $\mathrm{X}$ radiologi mobile ini terdiri dari system dan subsistem sinar $\mathrm{X}$ atau komponen. Sistem sinar $\mathrm{X}$ adalah seperangkat komponen untuk menghasilkan radiasi dengan cara terkendali. Sedangkan komponen untuk menghasilkan radiasi dengan cara terkendali. Sedangkan subsistem berarti setiap kombinasi dari dua atau lebih komponen system sinar X. Pesawat sinar X diagnostic yang lengkap terdiri dari sekurang-kurangnya generator tegangan tinggi, panel kontrol, tabung sinar $\mathrm{X}$, kolimator dan tiang penyangga tabung.

Ujang Wiharja (2019) melakukan uji akurasi tegangan tinggi alat Rontgen Radiography Umum untuk mengetahui nilai penyimpangan tegangan tabung $(\mathrm{kVp})$ masih dalam batas toleransi yang ditetapkan dalam PERKA BAPETEN No 9 Tahun 2011. Metode yang dilakukan adalah dengan mengukur tegangan keluaran tabung menggunakan detektor Piranha 657 dan mengukur jarak antara tabung X-Ray ke detektor dengan acuan pada PERKA BAPETEN No. 9 Tahun 2011.

Nur Mukminah R, telah melakukan penelitian uji kesesuaian pesawat sinar $\mathrm{X}$ ray merk GE Francis. Uji kesesuaian yang dilakukan hanya untuk mengetahui linearitas keluaran radiasi sinar X mobile sesuai dengan batas tolerasi yang telah ditentukan.

Pada penelitian ini dilakukan uji kesesuaian terhadap pesawat sinar $\mathrm{X}$ radiografi mobile merk DRGEM model TOPAZ-40D yang digunakan dalam pemeriksaan pasien covid-19. Uji kesesuaian ini bertujuan untuk mencegah paparan yang tidak diperlukan serta sebagai perwujudan dari program prioritas BAPETEN no 1 yaitu penguatan jaminan perlindungan keselamatan pasien radiologi. Metode yang dilakukan adalah dengan mengukur tegangan keluaran tabung menggunakan X-ray multimeter Piranha 557 dan mengukur jarak antara tabung X-Ray. Uji kesesuaian pesawat sinar $X$ radiografi mobile merk DRGEM model TOPAZ-40D meliputi parameter uji kolimasi berkas sinar $X$, generator dan tabung sinar X. Data alat ini diambil dari salah satu rumah sakit swasta di Surabaya.

\section{METODE PENELITIAN}

Sesuai PERBA BAPETEN No.2 Tahun 2018 untuk mengetahui pesawat sinar X ray tersebut andal maka dilakukan uji kesesuaian alat. Metode uji yang dipakai adalah uji kolomasi berkas cahaya, uji generator dan tabung sinar $\mathrm{X}$ ray.

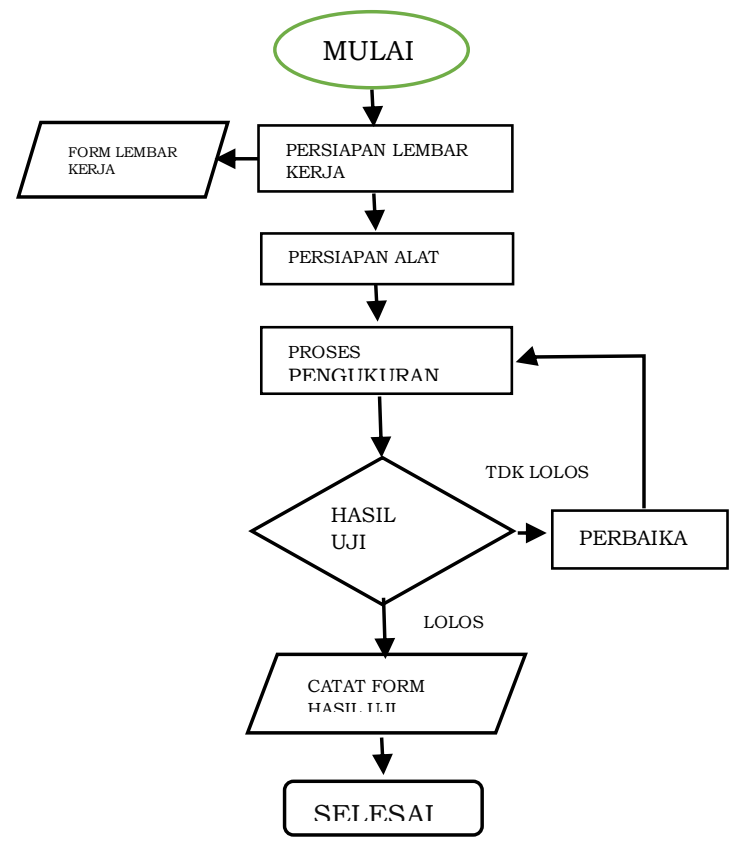

Gambar 2.1 Flowchart uji kesesuaian

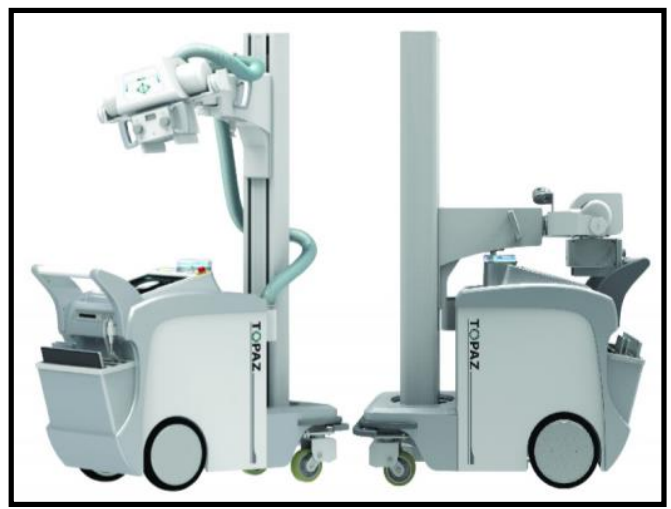

20| Journal Of Health Science 


\section{Alat}

Nama Alat : Pesawat X-Ray Radiografi mobile Merk : DRGEM, Tipe : TOPAZ 40D No Seri : DRR2040225A, Merk Tabung : DRGEM, Tipe Tabung : DXT-8, No Seri Tabung : M2004220

\section{Kondisi Lingkungan}

Suhu : $24^{\circ}$, Kelembaban : 60 \% RH

\section{Peralatan Uji}

1. X-Ray Multimeter Merk RTI Tipe Piranha 557 No Seri : CB2-13010691

2. Kolimator Tes Tool Merk Proproject

3. Survey Meter Merk Inspektor Tipe No Seri : 41083

4. Digital Waterpass Merk Local

5. Meteran Merk Krisbow Tipe Lokal No Seri : KW0104033

6. Thermohygrometer Merk HTC-1 Tipe 642

\subsection{Uji Kolimasi Berkas Cahaya}

1.Uji Illuminasi

Bertujuan mengukur tingkat pencahayaan yang diperoleh dari berkas cahaya kolimator. Perhitungan tingkat pencahayaan kolimator :

Illuminasi = rata-rata lux terukur-lux later

Nilai lolos uji $\geq 100$ lux

2.Uji Kolimasi

Bertujuan mengetahui selisih lapangan kolimasi dengan lapang berkas cahaya.

$$
\begin{aligned}
& \Delta \mathrm{X}\left(\% \mathrm{SID}-\frac{|\mathrm{X} 1|+|\mathrm{X} 2|}{\mathrm{SID}} \mathrm{x}\right. \\
& \Delta \mathrm{Y}(\% \mathrm{SID}) \quad-\frac{|\mathrm{Y} 1|+|\mathrm{Y} 2|}{\mathrm{SID}} \times \mathrm{x} \quad \ldots(2) \\
& \Delta \mathrm{X}+\Delta \mathrm{Y}=|\Delta \mathrm{X}|(\% \mathrm{SID})+|\Delta \mathrm{Y}|(\% \mathrm{SID})
\end{aligned}
$$

Nilai lolos uji :

$$
\Delta \mathrm{X} \text { dan } \Delta \mathrm{Y} \leq 2 \% \mathrm{SID}
$$$$
\Delta \mathrm{X}+\Delta \mathrm{Y} \leq 3 \% \mathrm{SID}
$$

\subsection{Uji generator dan tabung}

1. Uji akurasi tegangan

Bertujuan untuk melihat kesesuaian antara tegangan setting pada panel kontrol dengan nilai yang terbaca pada alat ukur $\mathrm{V}_{\text {n.set }}-k \mathrm{~V}_{n . u k u r}$

$$
\text { Error }=\frac{}{k \mathrm{~V}_{p . u}} x
$$

Dengan

$\mathrm{kV}_{\mathrm{p}, \text { set }}=$ tegangan pada panel kendali

$\mathrm{kV}_{\mathrm{p}, \mathrm{ukur}}=$ tegangan yang terukur pada

$$
\mathrm{kV}_{\text {pmeter }}
$$

Batas lolos uji e $\leq 10 \%$

2. Akurasi waktu penyinaran

Bertujuan untuk melihat kesesuaian antara setting waktu ekspose pada panel control dengan waktu ekspose yang terbaca pada alat ukur.

$$
\text { Error }=\frac{t_{\text {ukur }}-t_{\text {set }}}{t_{\text {set }}} x
$$

dengan :

$t_{\text {set }}=$ waktu eksposi pada panel kendali

$\mathrm{t}_{\mathrm{ukur}}=$ waktu eksposi pada alat ukur

Batas lolos uji e $\leq 10 \%$

3.Uji linearitas

Bertujuan untuk menguji konsistensi nilai keluaran radiasi (mGy/mAs) pada variasi $\mathrm{mA}$ atau $\mathrm{mAs}$. Dosis hasil pengukuran dalam $\mu \mathrm{Gy} / \mathrm{mAs}$.

Jika menggunakan Variasi mA, gunakan

$$
\mu \mathrm{Gy} / \mathrm{mAs} \quad \frac{\mu \mathrm{Gy}}{(\mathrm{mA} . \mathrm{s})}
$$

Menghitung koefisien linearitas:

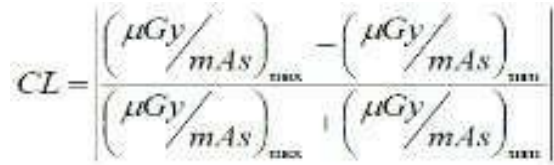

Atau dengan software pengolah data(calculator,excel) hitung nilai $(\mu \mathrm{Gy} / \mathrm{mAs})$,plot data antara list $\mathrm{mA}$ atau mAs dengan ( $\mu \mathrm{Gy} / \mathrm{mAs})$,kemudian buat grafik garis lurus (liniear) dan hitung/tampilan koefisien regresi linear R. Nilai R adalah koefisien linearitas (CL).

4. Uji reproduksibilitas

Untuk memeriksa konsistensi keluaran radiasi, tegangan dan waktu pada beberapa eksposi dalam pengaturan generator yang tetap.

- Keluaran radiasi :

$$
S D=\sqrt{\sum_{i-1}^{n} \frac{\left(\mu G y_{i}-\overline{\mu G y}\right)^{2}}{n-1}}
$$

$\mathrm{n}$ adalah banyaknya pengukuran, $\mu \mathrm{G} y$ adalah $\mu \mathrm{G} y$ rata-rata

- Tegangan puncak:

$$
S D=\sqrt{\sum_{i-1}^{n} \frac{\left(k V p_{i}-\overline{k V p}\right)^{2}}{n-1}}
$$

$\mathrm{kVp}$ adalah $\mathrm{kVp}$ rata-rata

- Waktu eksposi:

$$
S()=\sqrt{\sum_{i-1}^{n} \frac{\left(m s_{i}-\overline{m s}\right)^{2}}{n-1}}
$$

21| Journal Of Health Science 
$\mathrm{n}$ adalah banyaknya pengukuran, ms adalah ms rata-rata

- Menghitung koefisien variasi (CV)

Keluaran radiasi $C V=\underline{S D}$

$\mu G y$

Waktu eksposi $C V=\underline{S D}$

Tegangan puncak $C V=\underline{S D}$

$k V p$

Perhitungan nilai CV dapat juga dihitung dengan software pengolah data dengan menghitung nilai SD dan CV dari hasil pengukuran keluaran radiasi/waktu eksposi/tegangan puncak.

5. Uji kualitas berkas (HVL) bertujuan untuk menilai kualitas berkas sinar $\mathrm{X}$ dan kecukupan filtrasi untuk menyaring radiasi sinar $X$ energy rendah. Nilai HVL = nilai HVL yang terbaca pada alat ukur, Menggunakan alat ukur HVL dan tidak ada pengaturan untuk $80 \mathrm{kVp}$, Plot kVpterukur versus HVL terukur, Menggunakan kalkulator atau excel (pengolah data) buat grafik garis lurus., Tentukan persamaan linieritas, Hitung HVL pada $80 \mathrm{kVp}$, menggunakan dosimeter, Plot paparan radiasi yang terukur versus ketebalan filter yang digunakan, Menggunakan kalkulator atau excel (pengolah data) buat grafik garis lurus, Nilai HVL adalah nilai ketebalan filter pada titik tengah (separo) dari paparan radiasi yang terukur, Atau dapat juga menggunakan rumus

$$
H V I_{i}=\frac{t_{1} \ln \left(2 D_{2} / D_{0}\right)-t_{2} \ln \left(2 D_{1} / D_{0}\right)}{\ln \left(D_{2} / D_{1}\right)}
$$

$\mathrm{D}_{0}=$ dosis yang terukur tanpa filter

$\mathrm{D}_{1}=$ dosis yang lebih kecil dari $1 / 2 \mathrm{D}_{0}$

$D_{2}=$ dosis yang lebih besar dari $1 / 2 D_{0}$

$\mathrm{t}_{1}=$ ketebalan alumunium pada $\mathrm{D}_{1}$

$\mathrm{t}_{2}=$ ketebalan alumunium pada $\mathrm{D}_{2}$

Nilai Lolos Uji HVL $\geq 2.1 \mathrm{mmAl}$ pada 70 $\mathrm{kVp}$

6. Uji kebocoran wadah tabung

Bertujuan untuk mengetahui posisi dan nilai kebocoran wadah tabung.

Perhitungan kebocoran

$$
\text { Leakage (L) }=\dot{X} \frac{m A_{\text {cont }}}{m A_{\text {set }}} \frac{1}{1000}\left(\frac{m G y}{j a m}\right)
$$

Dimana :
$X=$ laju dosis terukur( $\mu \mathrm{Gy} / \mathrm{jam})$

$k V_{\text {max }}=\mathrm{kVp}$ maksimum mesin $(\mathrm{kV})$

$k V_{\text {set }}=\mathrm{kVp}$ saat eksposi dilakukan $(\mathrm{kV})$

$m A_{\text {cont }}=$ Arus kontinu alat (mA).

$m A_{\text {set }}=$ Pengaturan $\mathrm{mA}$ saat eksposi dilakukan $(\mathrm{mA})$

- Nilai lolos uji:L $\leq 1 \mathrm{mGy} / \mathrm{jam}$

HASIL DAN PEMBAHASAN

A. Uji kolimasi berkas sinar X

1.Uji Iluminasi

\begin{tabular}{|c|c|c|}
\hline $\begin{array}{c}\text { Area } \\
\text { penyinar }\end{array}$ & Titik ukur & $\begin{array}{l}\text { Pengukuran } \\
\text { (Lux) }\end{array}$ \\
\hline an 25 & Area 1 & 475 \\
\hline$c m x$ & Area 2 & 473 \\
\hline & Area 3 & 471 \\
\hline SID 100 & Area 4 & 470 \\
\hline $\mathrm{cm}$ & Rerata (Lux) & 473 \\
\hline & $\begin{array}{l}\text { Cahaya latar } \\
\text { (Lux) }\end{array}$ & 180 \\
\hline & FK & 0.02 \\
\hline & $\begin{array}{l}\text { Hasil Uji } \\
\text { (Lux) }\end{array}$ & 293 \\
\hline & $\begin{array}{l}\text { Nilai lolos } \\
\text { uji }\end{array}$ & $\geq 100$ lux \\
\hline
\end{tabular}

Tabel 1. Hasil uji iluminasi

2.Selisih lapangan kolimasi dengan berkas sinar-X

\begin{tabular}{|c|c|c|}
\hline \multirow{9}{*}{$\begin{array}{c}\text { Area } \\
\text { penyinar } \\
\text { an } 18 \mathrm{~cm} \\
\times 14 \mathrm{~cm} \\
k V p-s e t \\
55\end{array}$} & $\begin{array}{l}\text { Titik } \\
\text { ukur }\end{array}$ & $\begin{array}{l}\text { Tepi lap. cahaya } \\
\text { (cm) }\end{array}$ \\
\hline & $\mathrm{X}_{1}$ & 9 \\
\hline & $\mathrm{X}_{2}$ & 9 \\
\hline & $\mathrm{Y}_{1}$ & 7 \\
\hline & $\mathrm{Y}_{2}$ & 7 \\
\hline & $\begin{array}{c}\left|\Delta_{1}\right|+ \\
\left|\Delta_{2}\right| \\
(\% \text { SID) }\end{array}$ & 1.2 \\
\hline & $\begin{array}{c}\left|\Delta_{1}\right|+ \\
\left|\Delta_{2}\right| \\
(\% \text { SID })\end{array}$ & 1.3 \\
\hline & $\begin{array}{c}\Delta \mathrm{X}+ \\
\Delta \mathrm{Y} \\
(\% \mathrm{SID})\end{array}$ & 2.5 \\
\hline & $\begin{array}{l}\text { Nilai } \\
\text { lolos uji }\end{array}$ & $\begin{array}{l}\Delta \mathrm{X} \text { dan } \Delta \mathrm{Y} \leq 2 \% \\
\text { SID, } \quad|\Delta \mathrm{X}|+|\Delta \mathrm{Y}| \\
\leq 3 \% \text { SID }\end{array}$ \\
\hline$\Delta \mathrm{X}(\% \mathrm{SID})$ & $\begin{array}{l}- \\
=\underline{0} \\
=0,6\end{array}$ & $\begin{array}{l}\frac{11+|\mathrm{X} 2|}{\mathrm{SID}} \times \mathrm{x} \times 100 \% \\
+0,4 \times 100 \%\end{array}$ \\
\hline
\end{tabular}

Tabel 2. Hasil uji selisih lapangan kolimasi

22 | Journal Of Health Science 


$$
\begin{aligned}
\Delta \mathrm{Y}(\% \mathrm{SID}) & -\frac{|\mathrm{Y} 1|+|\mathrm{Y} 2|}{\mathrm{SID}} \times 100 \% \\
& =\frac{0,4+0,{ }^{\circ}}{100} \times 100 \%
\end{aligned}
$$

$$
\begin{aligned}
\Delta \mathrm{X}+\Delta \mathrm{Y} & =|\Delta \mathrm{X}|(\% \mathrm{SID})+|\Delta \mathrm{Y}|(\% \mathrm{SID}) \\
& =0,6+0,7 \\
& =1,3
\end{aligned}
$$

3.Ketegaklurusan berkas sinar X

Tabel 3 uji ketegaklurusan berkas sinar X

\begin{tabular}{lcc}
\hline \multirow{2}{*}{ Ketegaklurusan } & Hasil ukur $\left(^{\circ}\right)$ & Nilai lolos uji \\
\cline { 2 - 3 } & 1 & $3^{\circ}$ \\
\hline
\end{tabular}

Ketegaklurusan berkas sinar $\mathrm{X}$ diukur berdasarkan pergeseran titik pusat penyinaran pada film.

Gambar 4.1. illustrasi Kolimator tes

$$
\begin{aligned}
\tan \theta & =\frac{\mathrm{ab}}{\mathrm{ae}} \\
\frac{\mathrm{de}}{\mathrm{ab}} & =\frac{\mathrm{ce}}{\mathrm{ac}} \Rightarrow \mathrm{ab}=\frac{\mathrm{de} \times \mathrm{ac}}{\mathrm{ce}}
\end{aligned}
$$

$\tan \theta=\frac{\text { de } x \text { ac }}{\text { ae } \times \text { ce }}$

\section{B. Uji generator dan tabung sinar $X$}

1. Uji Akurasi tegangan

Tabel 4 Hasil uji Akurasi tegangan

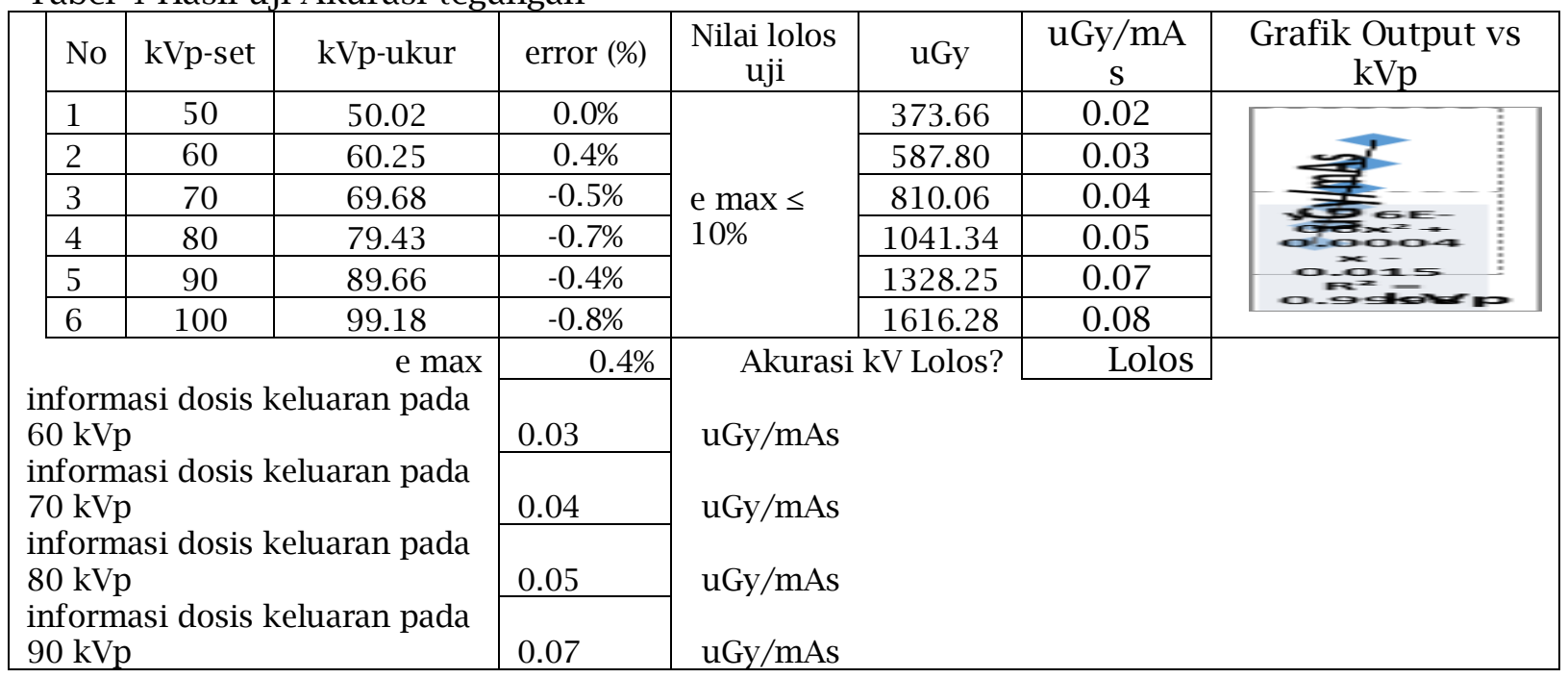

Error $=\frac{k \mathrm{~V}_{\text {p.ukur }}}{k \mathrm{~V}_{\text {n.set }}-k \mathrm{~V}_{\text {n.ukur }}} \times 100=0,4 \%$

2.Uji akurasi Waktu penyinaran

Tabel 5 Hasil uji Akurasi waktu penyinaran

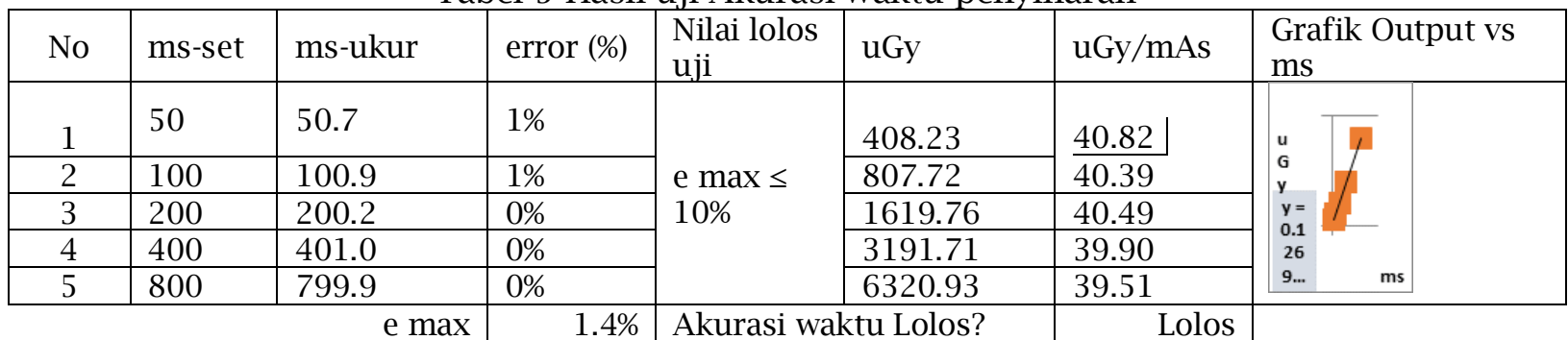

Pada tabel 5 diatas prosentase error yang diperoleh pada setiap perhitungan dibandingkan dan diambil nilai error yang maksimum yaitu dibawah $10 \%$. 


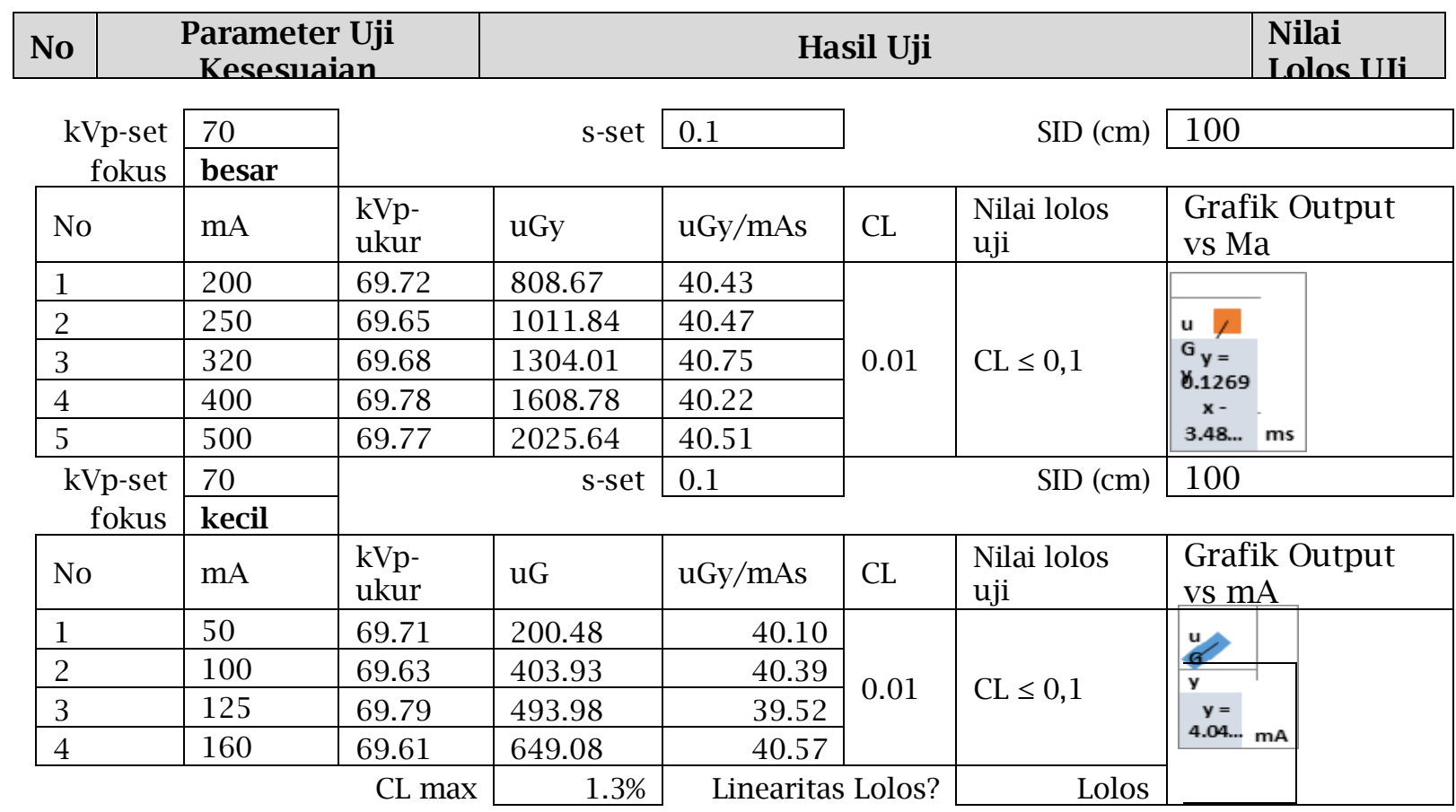

3. Uji linieritas

Tabel 6 Hasil uji Akurasi linieritas

Pada uji linieritas dilakukan pada semua variasi $\mathrm{mA}$ dan $\mathrm{mAs}$ yang berbeda. $\mathrm{mA}$ besar diambil pada rentang 200-500mA, sedangkan mA kecil diambil pada rentang 50-160 mA, untuk mengetahui nilai koefisien linieritas dapat dihitung dengan cara sebagai berikut:

$$
\begin{aligned}
\mathrm{CL} & =\frac{40,75-40,22=0,53=0,01 \text { (fokus besar) }}{40,74+40,2280,96} \\
\mathrm{CL} & =\frac{40,57-39,52}{40,57+40,22 \quad 80,09}=0,01 \text { (fokus kecil) }
\end{aligned}
$$

\begin{tabular}{|c|c|c|c|c|}
\hline \multirow{2}{*}{$\begin{array}{l}\text { kVp-set } \\
\text { fokus }\end{array}$} & \multirow{2}{*}{$\begin{array}{l}70 \\
\text { besar }\end{array}$} & & \multirow{2}{*}{$\begin{array}{r}\mathrm{mA} \text {-set } \\
\text { s-set }\end{array}$} & \multirow{2}{*}{$\begin{array}{l}200 \\
0.1 \\
\end{array}$} \\
\hline & & & & \\
\hline & No. & $\mathrm{kV}$ & $\mathrm{S}$ & uGy \\
\hline & 1 & 69.67 & 0.100 & 808.72 \\
\hline & 2 & 69.60 & 0.100 & 809.13 \\
\hline & 3 & 69.50 & 0.100 & 810.58 \\
\hline & 4 & 69.72 & 0.100 & 810.65 \\
\hline & 5 & 69.68 & 0.100 & 810.06 \\
\hline & Rerata & 69.63 & 0.100 & 809.83 \\
\hline & Std & 0.0883 & 0.0000 & 0.8676 \\
\hline & $\mathrm{CV}$ & 0.001 & 0.000 & 0.001 \\
\hline & & $\mathrm{CV} \leq 0,05$ & & \\
\hline
\end{tabular}

4.Uji reproduksibilitas tegangan, waktu dan dosis penyinaran

Tabel 7 Hasil uji reproduksibilitas tegangan

Keluaran radiasi :

$$
\begin{aligned}
S D & =\sqrt{\sum_{i=1}^{n} \frac{\left(\mu G y_{i}-\overline{\mu G y}\right)^{2}}{n-1}} \\
& =\underline{809,83}=0,001
\end{aligned}
$$

Waktu eksposi :

$$
\begin{aligned}
S() & =\sqrt{\sum_{i-1}^{n} \frac{\left(m s_{i}-\overline{m s}\right)^{2}}{n-1}} \\
& =\underline{0,000}=0,000
\end{aligned}
$$

Tegangan puncak :

$$
\begin{aligned}
S D & =\sqrt{\sum_{i-1}^{n} \frac{\left(k V p_{i}-\overline{k V p}\right)^{2}}{n-1}} \\
& =\underline{0,0883}=
\end{aligned}
$$




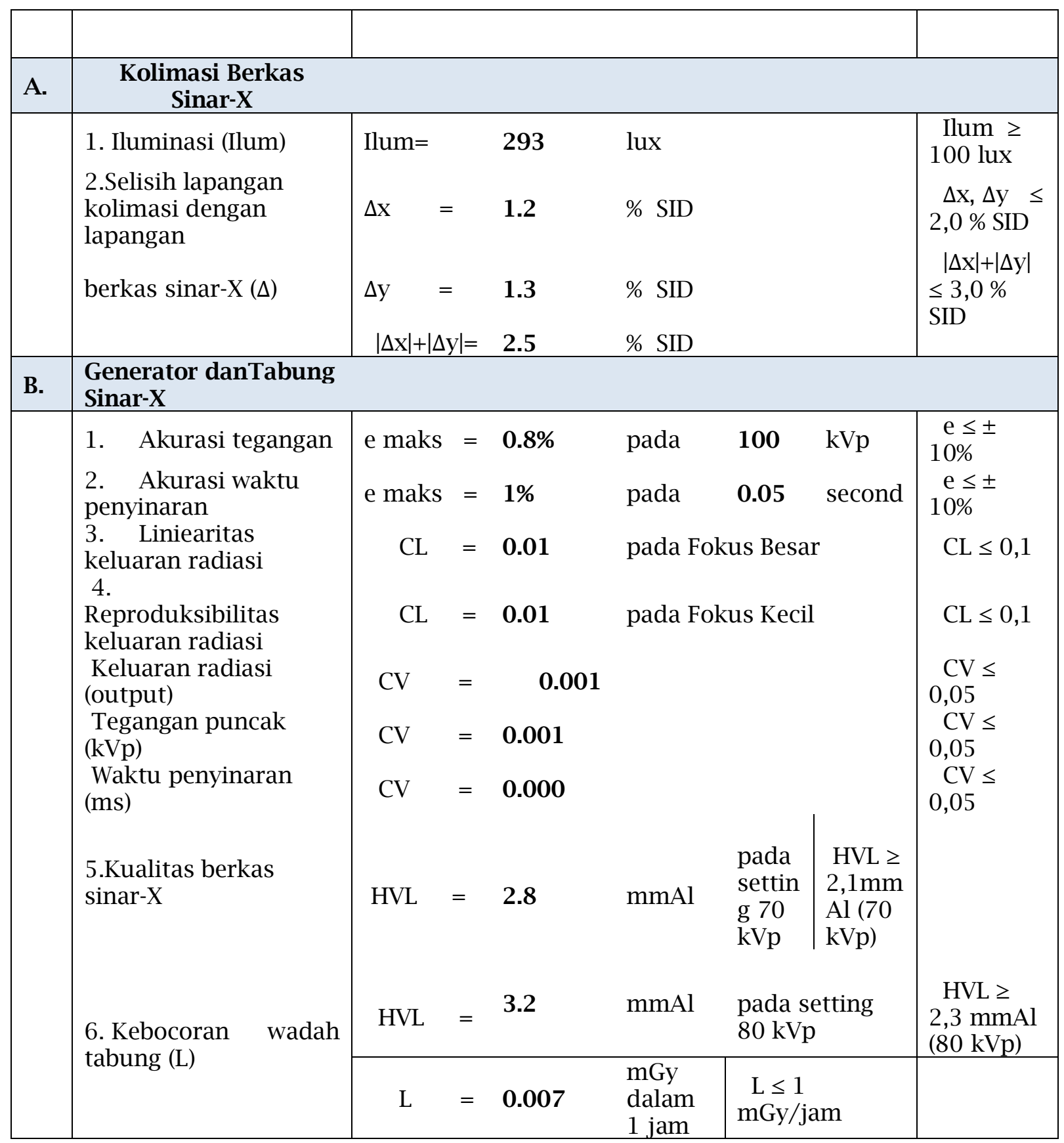

\section{RESUME HASIL UJI \\ KESIMPULAN}

Uji kesesuaian pesawat sinar $\mathrm{X}$ radiography mobile merk DRGEM type Topaz-40 D bertujuan untuk mencegah paparan yang tidak diperlukan serta sebagai perwujudan dari program prioritas BAPETEN no 1 yaitu penguatan jaminan perlindungan keselamatan pasien radiologi. Dari data diatas semua parameter uji kesesuaian pesawat sinar $X$ radiography mobile merk DRGEM type Topaz-40 D dinyatakan
ANDAL. Hal ini dilihat uji iluminasi berkas kolimator didapatkan hasil 292,25 lux, uji Selisih lapangan kolimasi dengan berkas sinar- $X$ dinyatakan dalam rentang nilai lolos uji dimana nilai $\Delta \mathrm{X}=0,6$ dan $\Delta \mathrm{Y}=0,7, \mathrm{Uji}$ ketepatan berkas/aligment obyek menunjukkan penyimpangan titik pusat penyinaran pada film sebesar 1 derajat, Uji akurasi tegangan tabung sinar $\mathrm{X}$ error maksimal didapat 0,4 . Uji akurasi waktu penyinaran dilakukan dengan faktor

25| Journal Of Health Science 
eksposi $\mathrm{kVp}$ tetap pada focus besar, hasil uji menunjukkan nilai simpangan / error 1,4 \% ( dibawah $10 \%$..), Koefisien linieritas yang diperoleh berdasarkan uji keluaran (output) radiasi sebesar 0,047 sedangkan nilai CL yang diperkenankan yaitu $\leq 0,1$. Coefisien of Variation (CV) yang diperoleh Coefisien of Variation tegangan $(\mathrm{kVp})=$ 0,001 , Coefisien of Variation waktu $(\mathrm{s})=$ 0,000 , Coefisien of Variation paparan radiasi $(m G y)=0,001$, sedangkan nilai Coefisien of Variation (CV) yang diperkenankan ialah $\leq 0,05$.

Pada uji kualitas berkas (HVL) menggunakan settingan 70 dan $80 \mathrm{Kv}$ dengan filter permanen. Hasil ukur menunjukkan kisaran 2,8 mmAl dan 3,2 mmAl. sedangkan nilai lolos uji yaitu $\geq 2,3$ mmAl. Uji kebocoran tabung, didapatkan nilai $0.007 \mathrm{mGy} / \mathrm{jam}$ hasil pengukuran ini masih dalam rentang nilai lolos uji $(<1 \mathrm{mGy} / \mathrm{jam})$ sesuai ketentuan PERBA BAPETEN No.2 Tahun 2018. Pengujian informasi dosis pasien tidak dilakukan menurut PERBA no.2 tahun 2018.

\section{UCAPAN TERIMA KASIH}

PT. Mulya Husada Jaya yang sudah mengizinkan dalam penelitian bersama. Semua jajaran pimpinan dan citivitas akademik Universitas Kadiri khususnya fakultas ilmu kesehatan

\section{DAFTAR PUSTAKA}

Badan Pengawas Tenaga Nuklir Republik Indonesia. Peraturan Badan Pengawas Tenaga Nuklir Republik Indonesia Nomor 2 Tahun 2018 Tentang Uji Kesesuaian Pesawat Sinar-X

BAPETEN. Peraturan Perundang-undangan Ketenaganukliran Bidang Fasilitas Radiasi dan Zat Radioaktif. 2008;

BAPETEN. Petugas Proteksi Radiasi Radiodiagnostik. 2008;

Hastuti P, Syafitri I, Susanto W. Uji Kesesuain sebagai Aspek Penting Dalam Pengawasan Penggunan Pesawat Sinar-X di Fasilitas Radiologi Diagnostik. Semin Nas Sains dan Teknol Nukl. 2009;269-77.

IAEA Safety Standards Radiation Protection and Safety of Radiation Sources

IAEA Training Material on Radiation Protection in Diagnostic and Interventional Radiology
Jauhari A. Bekas Sinar -X dan Pembentukan Gambar. 2008;

Keputusan Direktur Keteknikan dan Kesiapsiagaan Nuklir Nomor: 0001/DK2N/I/2020 Tentang: Petunjuk Teknis Parameter Uji Kesesuaian Pesawat Sinar-X Radiologi Diagnostik dan Intervensional

Mukminah N, Iswadi, Ihsan. X-Ray Mobile Dengan Menggunakan Piranha. AlKimia. 2014; VOL 2, NO(ISSN 23022736):76-85.

PP No.29 Tahun 2008 Tentang Perijinan Pemanfaatan Sumber Radiasi Pengion dan Bahan Nuklir

PP No.33 Tahun 2007 Tentang Keselamatan Radiasi dan Keamanan Sumber Radioaktif

Radiologi Diagnostik dan Intervensional. 2018;

Safety Series No. 115_1996 Basic Safety Standards for Protection and Safety of Radiation Source

Suprayitno, E., Rahmawati, S., Ragayasa, A., \& Pratama, M. Y. (2020). Pengetahuan dan Sikap Masyarakat dalam Pencegahan COVID-19. Journal of Health Science (Jurnal Ilmu Kesehatan), 5(2), 68-73.

Susanti R, Milvita D, Sandy KYP. Uji Kesesuaian Pesawat CT - Scan 64 Slice Merek Philips di Instalasi Radiologi Rumah Sakit Universitas Andalas Padang Menggunakan Detektor Unfors Raysafe X2. J Fis Unand. 2017;6(4):35561.

Suseno D, S K. Workshop Tentang Batas Toleransi Pengukuran Uji Kesesuaian Pesawat Sinar-X. 2008;

Wiharja U, Kodir A, Bahar A. Analisa Uji Kesesuaian Pesawat Sinar-X Radiografi. 2019;0-7. 